„TURYZM" 1992, z. 1

Andrzej Matczak

\title{
FOREIGN TOURIST TRIPS OF POLES
}

\section{LES DEPLACEMENTS TOURISTIQUES DES POLONAIS A L'ETRANGER}

\section{ZAGRANICZNE WYJAZDY TURYSTYCZNE POLAKÓW}

It is quite difficult to gather comparable data concerning foreign tourist trips of Poles in the postwar period. This is due to the tourist policy pursued by the State, changes introduced to methods of registering such trips, and ways of publicizing information about them, and finally to the country's socio-economic situation.

In the period following the Second World War Poland conducted a policy of a balanced exchange of tourists. There were periods when that policy was pursued very rigorously and periods during which it was relatively liberally executed. The state policy determined the volume and directions of trips abroad made by Poles, which were in principle a function of the volume of foreigners' trips to Poland. The tools of that policy included the administrative rationing of foreign currencies and passports, and its effect was a state controlled tourist traffic, which reflected to only an insignificant degree the real social preferences. It was not until 1989 that solutions in this field generally accepted in Western countries began to be introduced.

Initially, the data about Polish tourists travelling abroad were collected by passport-issuing agencies (passports were kept in a government office and issued to individuals for each trip abroad). That method did not provide accurate data about the number of persons who were really leaving Poland, because not all those obtaining passports would go abroad. The registration of persons travelling abroad was started in 1970 . It was based on special individual registration cards. Such an approach allowed the collection of information about means of transport used for travelling abroad and border crossings, while a seal with a date stamped 
on a registration card (date of departure and return) allowed the calculation of the number of days spent abroad. It was necessary to enter onto a card the registration number of the passport office issuing a passport, which generated information about places of origin of tourists going abroad. That system of registration was maintained till the end of the eighties. In 1989 registration of border crossing was adopted and registration cards were withdrawn. The data obtained in such a way were processed in the Central Statistical Office in the form of monthly reports needed by the Ministry of Internal Affairs, with aggregated data being later published in statistical publications in a more or less detailed manner. This generally accessible material is characterized by a high degree of aggregation and by incomparability over longer time periods.

Poland's permanently bad economic and social situation (especially on the consumer goods market); low earnings and huge unemployment in the last few years, accompanied by prices of goods and services only a little lower than in Western countries, and a high exchange rate of the dollar to the zloty all cause many Poles to give their preference to trips abroad aimed at making a profit from buying and selling goods or taking a job. Such trips have very little in common with true tourism. It is hard to assess today what percentage share of all registered trips (border crossings) are made for tourist purposes, however, it can be stated that it is very low share.

In the years immediately after the end of the Second World War tourist traffic was insignificant. In 1960 only a little over 200,000 persons managed to go abroad. The number of such trips rose relatively fast in the years 1960-1971, and in 1971 more than one million Poles travalled abroad (Fig. 1). An important role in that increase was played by the agreements concluded by the Polish Government with Czechoslovakia and East Germany on providing easy access for foreign tourists to their border zones within the framework of tourist conventions. In the sixties the number of Poles visiting the tourist convention zones of both these countries ranged from 300,000 to 500,000 . The border between Poland and East Germany was opened in 1972, which caused a rapid increase in the number of trips abroad exceeding 10 million persons a year in the second half of the seventies. Over that period trips to East Germany increased from 5.6 to 9.5 million Poles. The eighties witnessed a very substantial drop in the number of such trips. This was due to the closing of their borders for Poles by the neighbouring countries and briefly to the imposition of martial law in Poland. These events caused the number of persons travelling abroad to drop to one million in 1982. Since 1983 there has been a gradual compensatory increase in 


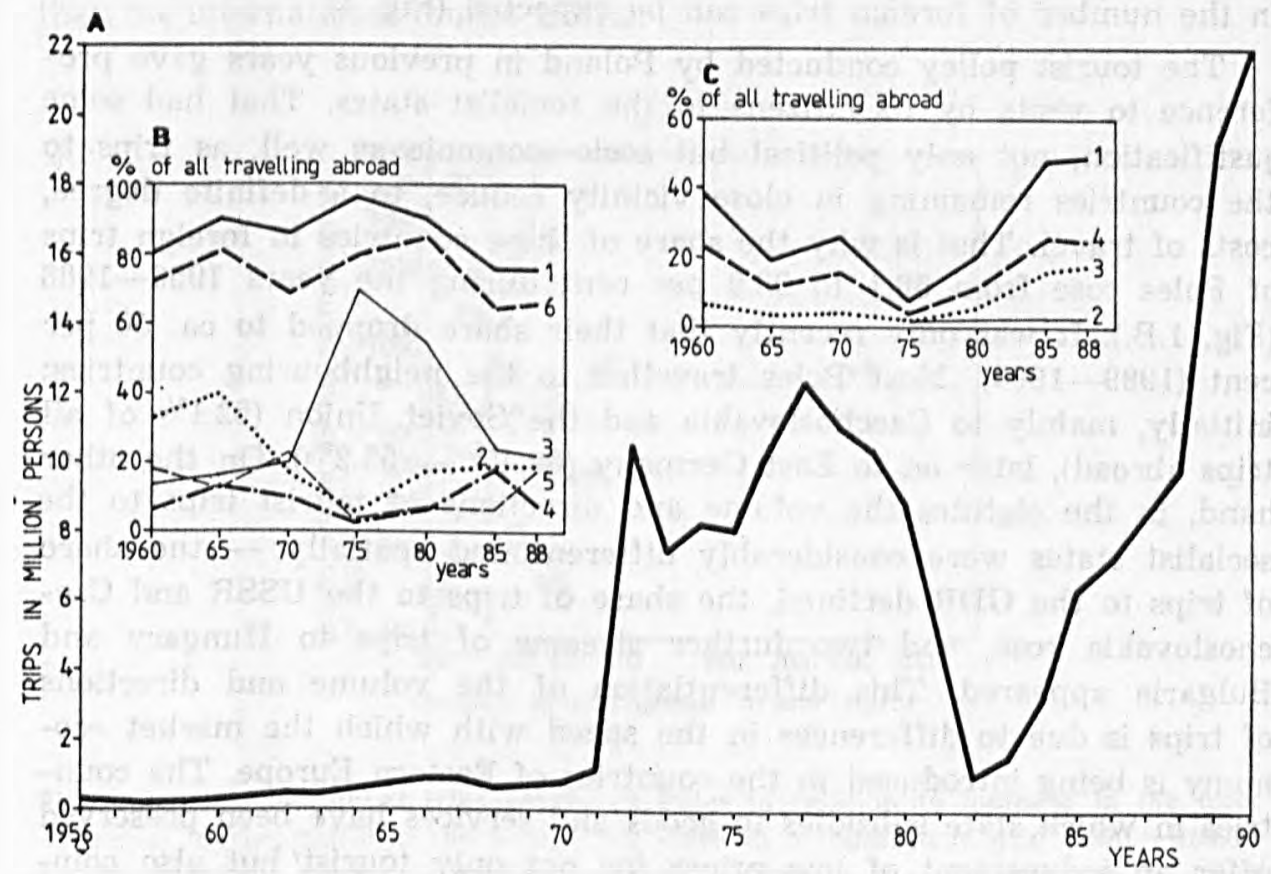

Fig. 1. Tourist trips of Poles abroad

A - volume of tourist trips abroad of Poles in the years 1956 - 1990; B - shares of the former socialist states in tourist trips abroad of Poles in the years 1960-1988: 1 - all socialist states taken together, 2 - Czechoslovakia, 3 - East Germany, 4 - Hungary, 5 - Soviet Union, 6 - Czechoslovakia, East Germany, Hungary and Soviet Union together, $\mathrm{C}$ - shares of the remaining countries in tourist trips abroad of Poles in the years 1960-1988: 1 - total, 2 - France, 3 - West Germany, 4 - five

Western countries taken together: France, West Germany, Great Britain, Italy and United States

Dessin 1. Les voyages touristiques des Polonais à l'étranger

A - dimension des voyages touristiques des Polonais à l'étranger dans les années 1956-1990; B - part des anciens pays socialistes dans les voyages touristiques des Polonais dans les années 1960-1988: 1 - total des anciens pays socialistes, 2 - Tchécoslovaquie, 3 - Allemagne de l'Est, 4 - Hongrie, 5 - Union Soviétique, 6 - Tchécoslovaquie, Allemagne de l'Est, Hongrie, Union Soviétique; C - part des autres pays dans les voyages touristiques des Polonais à l'étranger dans les années 1960-1988: 1 - total, 4 - France, 3 - Allemagne de l'Ouest, 4 - total des cinq pays occidentaux; France, Allemagne de l'Ouest, Grande Bretagne, Italie, Etats-Unis

the number of tourist trips abroad owing to a steady liberalization of restrictions imposed by the Gevernments of Poland and the neighbouring countries in relation to Polish nationals. Their number topped 10 million persons in 1988. The liberal passport and currency regulations introduced in the late eighties resulted in 19.3 million statistical border crossings by Polish tourists going abroad being recorded in 1989 and as many as 22 million already a year later. In the future, together with abolition of 
visa requirements for Poles by European countries, a further growth in the number of foreign trips can be expected (Fig. 1).

The tourist policy conducted by Poland in previous years gave preference to visits by its citizens to the socialist states. That had some justification, not only political but socio-economic as well, as trips to the countries remaining in close vicinity reduce, to a definite degree, costs of travel. That is why the share of these countries in foreign trips of Poles rose from 68.1 to 96.9 per cent during the years 1956-1988 (Fig. 1.B.). It was only recently that their share dropped to ca. 50 per cent (1989-1990). Most Poles travelled to the neighbouring countries; initially, mainly to Czechoslovakia and the Soviet Union $(52.1 \%$ of all trips abroad), later on to East Germany $(69.4 \%-55.2 \%)$. On the other hand, in the eighties the volume and directions of tourist trips to the socialist states were considerably differentiated spatially - the share of trips to the GDR declined, the share of trips to the USSR and Czechoslovakia rose, and two further streams of trips to Hungary and Bulgaria appeared. This differentiation of the volume and directions of trips is due to differences in the speed with which the market economy is being introduced in the countries of Eastern Europe. The countries in which state subsidies to goods and services have been preserved offer an inducement of low prices for not only tourist but also commercial trips of Poles, e.g. a skiing trip to Czechoslovakia in the winter of 1990 -1991 was by almost 30 per cent cheaper than a similar trip anywhere in Poland.

The share of trips to Western countries tended to be quite low throughout the postwar period (Fig. 1.C.). Following periods of political upheaval in Poland it rose to ca. 20 per cent only to drop later to under 10 per cent despite strong ties linking Poles with societies of Western countries (maintained through people of Polish origin abroad whose number exceeds 10 million). The biggest number of trips was recorded to five Western countries: the FRG, Great Britain, Italy, and the United States - they always accounted for around 50 per cent of all trips abroad of Poles to nonsocialist countries. In the eighties, apart from the above mentioned countries, more Poles travelled to Sweden, West Berlin, Austria, Greece, and Turkey. In recent years these countries have been taking over almost a half of all Poles travelling to Western countries. Many of these tourist trips have also commercial and employment purposes.

In the period after 1970 the number of Poles' tourist trips to Western countries grew rapidly. The growth rate of these trips in the years 1970-1988 was higher than that recorded by the international tourist traffic (Fig. 2). On the other hand, trips made by Poles to the former 
socialist states, despite their large volume, increased at a lower rate than the international tourist traffic.

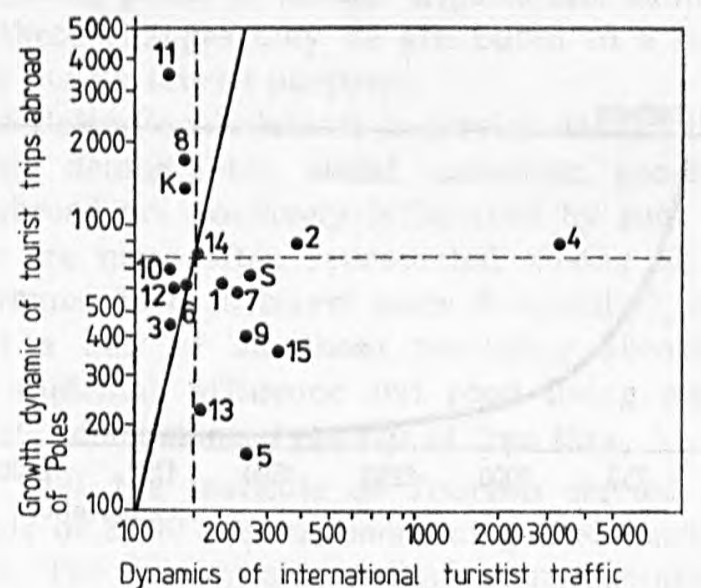

Fig. 2. Increase of tourist trips abroad of Poles in relation to increase in the international tourist traffic in the years $1970-1988$ in a logarithmic grid $(1970=100.0)$ $\mathrm{S}$ - former socialist states; $\mathrm{K}$ - remaining countries; 1 - Bulgaria; 2 - Czechoslovakia; 3 - Yugoslavia; 4 - East Germany; 5 - Rumania; 6 - Hungary; 7 - Soviet Union; 8 - Austria; 9 - France; 10 - Holland; 11 - West Germany; 12 - United States; 13 - Great Britain; 14 - Italy; 15 - Greeca

Dessin 2. Diagramme logarithmique de l'accroissement de voyages touristiques des Polonais à l'étranger par rapport à l'accroissement du mouvement touristique interna. tional dans les années 1970-1988 (année $1970=100,0$ )

S - anciens pays socialistes, $\mathrm{K}$ - autres pays; 1 - Bullgarie; 2 - Tchécoslovaquie; 3 - Yougoslavle; 4- Allemagne de l'Est; 5 - Roumanie; 6 - Hongrie; 7 - Union Soviétique; 8 - Autriche; 9 France; 10 - Hollande; 11 - Allemagne de l'Ouest; 12 - Etats-Unis; 13 - Grande Bretagne, 14 Italie; 15 - Grèce

The share of Polish tourists in the total number of visits to the former socialist countries is of great importance for them. In 1988 Polish tourists represented a little over one-fourth of all foreigners visiting the Soviet Unions, over 15 per cent in the GDR, about 10 per cent each in Czechoslovakia, Bulgaria and Hungary, 3.5 per cent in Yugoslavia, and 1 per cent in Rumania. Meanwhile, the share of Polish tourists in Western countries, despite its rapid increase in the last few years, continues to be very small: in Austria - 0.9 per cent. in France - 0.2 per cent, in Great Britain - 0.3 per cent, in the United States -0.2 per cent, and in Italy -0.4 per cent. Only in the FRG this share was quite significant -6.7 per cent. Quite large shares of Polish tourists were recorded, among others, in Greece $(2.2 \%)$ and Turkey (Fig. 3). 
The volume of foreign trips made by Poles is strongly correlated with the distance. The graph (Fig. 3) presenting distances of trips estimated in a straight line between Warsaw and the capital cities of particular European countries and the volume of tourist trips, shows

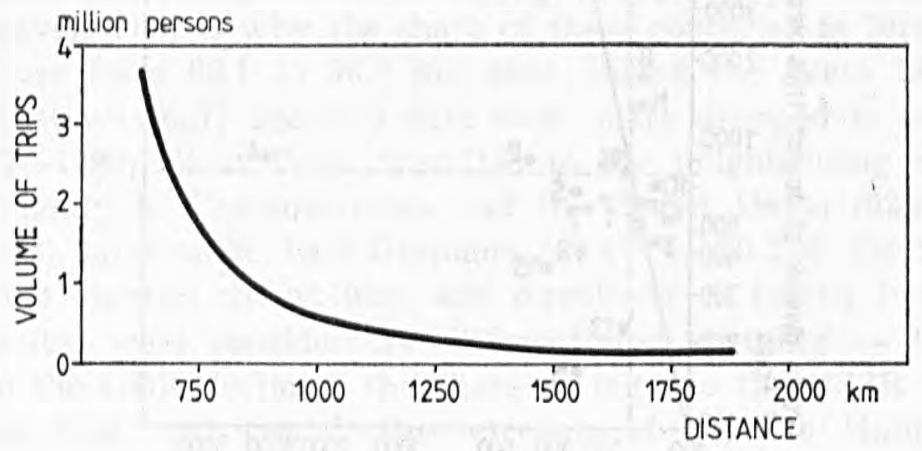

Fig. 3. Volume of tourist trips abroad of Poles according to a distance to places of destination in 1988

Dessin 3. Dimension des voyages touristiques des Polonais à l'étranger par rapport à l'éloignement du but de voyage en 1988

a significant negative correlation. The number of trips decreases proportionally to increasing distances.

Foreign trips of Poles are spread much more evenly over the year

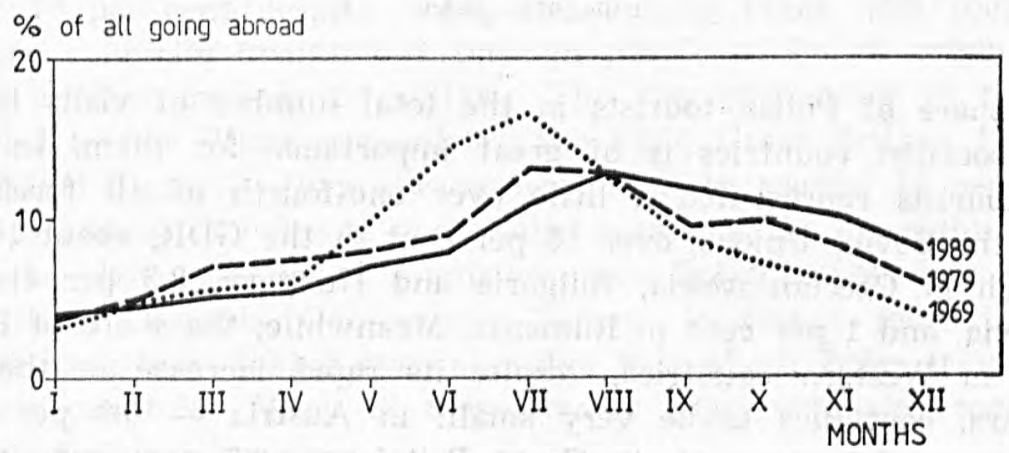

Fig. 4. Seasonality of tourist trips abroad of Poles in the years 1969-1989

Dessin 4. Saisonnalité des voyages touristiques des Polonais à l'étranger dans les années 1969-1989 
than tourist trips within Poland. In the period 1969-1989 there took place major changes in seasonality of trips abroad (Fig. 4). The general trend of these changes consists in a steady flattening of the seasonality curve and in shifting peaks of foreign trips to late summer and autumn. It seems that these changes may be attributed to a declining share of trips abroad for purely tourist purposes.

The share of Poland's inhabitants in foreign tourist trips is dependent upon very many demographic, social, economic, geographic and other factors. Trips abroad are positively influenced by such variables as age (young persons are more often represented among all those travelling abroad), sex (women tend to travel more frequently), educational background (almost a half of all those travelling abroad are university graduates and students), affluence and good living conditions, as well as the availability of substantial periods of free time.

In January 1991 the Institute of Tourism carried out a survey of a random sample of 2,000 persons concerning their participation in trips abroad in 1990. The survey shows that young people aged 25 to 29 and those aged 40 to 44 constituted the biggest shares of those travelling abroad (ca. $21 \%$ each), followed by persons between 20 and 24 , and between 35 and 39 years of age (ca. 16-17\% each). Older persons $(6 \%)$ and very old persons $(1 \%)$, were travelling abroad most seldom From among those aged 20 to 29 every third, and those aged 30 to 39 every second, travelled abroad more than once. Almost a half of people going abroad stay there for a very short time - most often 2 to 3 days. The others stay longer - over 5 days. The goal of one-third of all trips abroad was tourism and recreation. A similar share was accounted for by trips connected with shopping, temporary employment, etc. The goal of the remaining trips was to visit relatives and friends, or these were business trips.

Over two-thirds of all those travelling abroad come from strongly urbanized areas of Poland (Fig. 5.). Trips abroad are dominated by inhabitants of the capital city of Warsaw and its region and the administrative provinces in the south of Poland, especially from Katowice, Cracow and Wroclaw provinces, and to a smaller degree those from the administrative counties of Łódź, Poznań, Lublin, Gdańsk and Szczecin. A' very small number of inhabitants of the agricultural regions of Poland travel abroad. Western countries are mainly visited by inhabitants of large cities: Warsaw, Eódź, Cracow, the cities of Upper Silesia, Opole, Wrocław and Gdańsk. They also predominate in travels to the former socialist states, with a bigger regionalization being observed in these trips. For example, inhabitants of the southern regions of Poland form predominant groups of tourists going to Czechoslovakia 
A
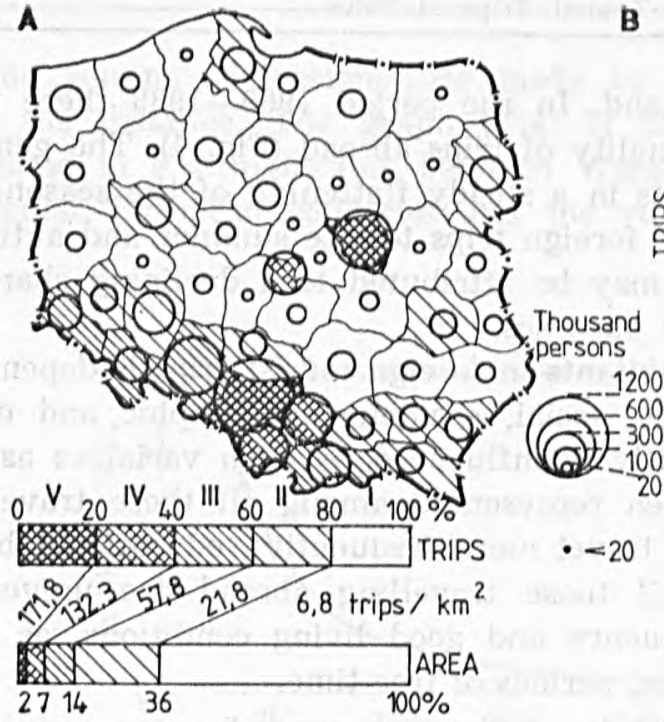

B

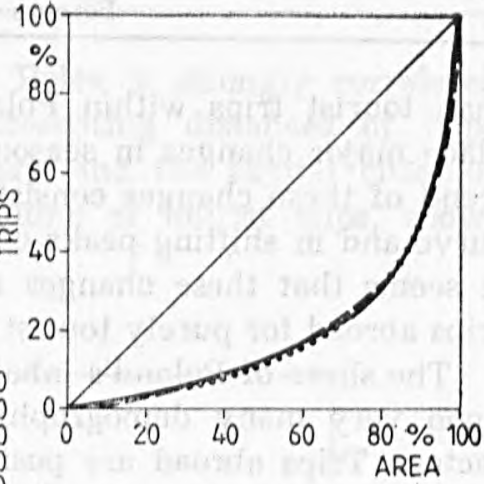

$\cdot<20$

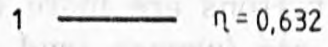

$2-\cdots=0,623$

3 …........ $\eta=0,648$
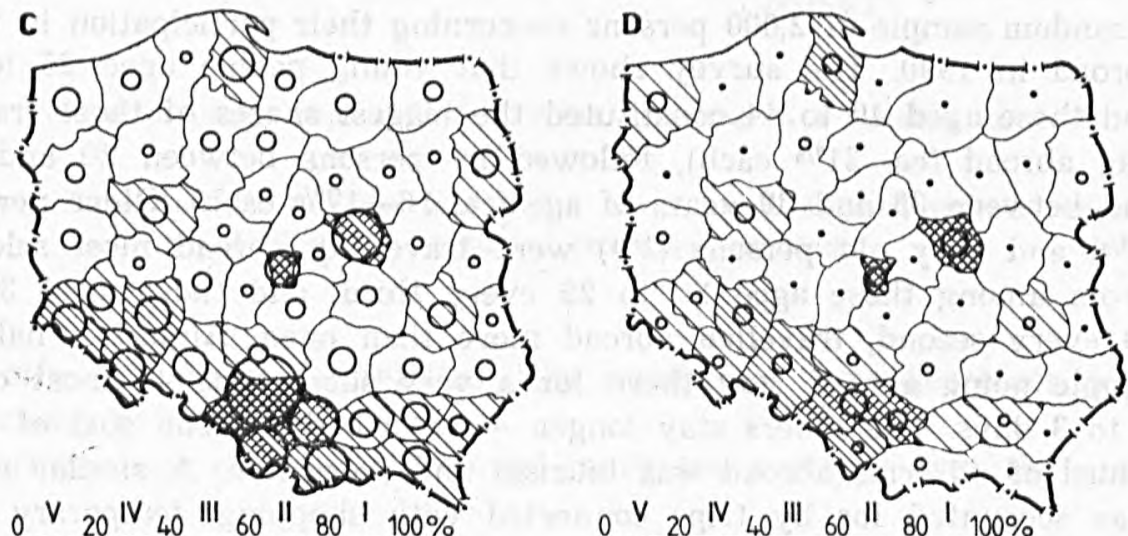

$0^{V_{2}}$ IV $_{40}$ III $60^{\prime \prime} 80^{\prime} 100 \%$
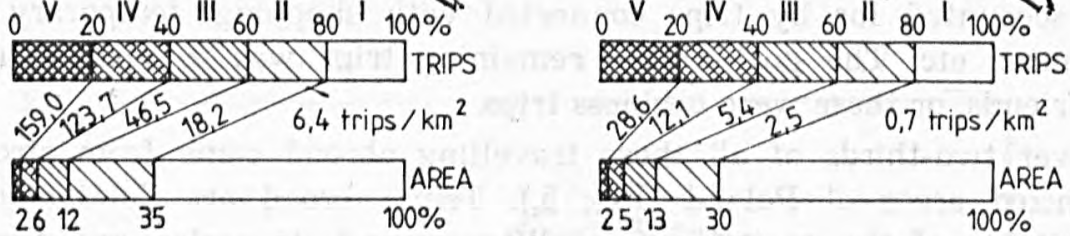

Fig. 5. Dwelling places of Poles taking part in tourist trips abroad in 1980 A - total; B - curvé of concentration: 1 - dwelling places of Poles taking part in tourist trips abroad in 1980 (total), 2-dwelling places of Poles taking part in tourist trips abroad to former socialist states, 3 - dwelling places of Poles taking part in tourist trips to remaining countries; C - dwelling places of Poles taking part in tourist trips to former socialist states in 1980 ; D - dwelling places of Poles taking part in tourist trips to remaining countries in 1980

Dessin 5. Lieu d'origine des Polonais participant aux voyages touristiques à l'étranger en 1980

A - au total; B - courbe de concentration: 1 - des domiciles des Polonais participant au total des voyages touristiques à l'étranger en 1980, 2 - du domicile des Polonais participant aux voyages touristiques en anciens pays socialistes, 3 - du domicile des Polonais participant aux voyages touristiques en autres pays; C - lieu d'origine des Polonais participant aux voyages touristiques en anciens pays socialistes en $1980 ; \mathrm{D}$ - lieu d'origine des Polonais participant aux voyages touristiques 
and Hungary; those from the region of Warsaw and, to a smaller extent, from the other agglomerations, going to the Soviet Union and Bulgaria.

Dr Andrzej Matczak

Zakład Geografii Miast i Turyzmu Instytut Geografii Ekonomicznej

i Organizacji Przestrzeni

Uniwersytet Łódzki

al. Kościuszki 21

90-418 Łódź
Wpłynęło:

30 października $1991 \mathrm{r}$. 